\title{
Assessing water resources adaptive capacity to climate change impacts in the Pacific Northwest Region of North America
}

\author{
A. F. Hamlet \\ Department of Civil and Environmental Engineering, University of Washington, USA \\ Climate Impacts Group, University of Washington, USA \\ Received: 1 May 2010 - Published in Hydrol. Earth Syst. Sci. Discuss.: 8 July 2010 \\ Revised: 5 March 2011 - Accepted: 7 March 2011 - Published: 6 May 2011
}

\begin{abstract}
Climate change impacts in Pacific Northwest Region of North America (PNW) are projected to include increasing temperatures and changes in the seasonality of precipitation (increasing precipitation in winter, decreasing precipitation in summer). Changes in precipitation are also spatially varying, with the northwestern parts of the region generally experiencing greater increases in cool season precipitation than the southeastern parts. These changes in climate are projected to cause loss of snowpack and associated streamflow timing shifts which will increase cool season (October-March) flows and decrease warm season (AprilSeptember) flows and water availability. Hydrologic extremes such as the $100 \mathrm{yr}$ flood and extreme low flows are also expected to change, although these impacts are not spatially homogeneous and vary with mid-winter temperatures and other factors. These changes have important implications for natural ecosystems affected by water, and for human systems.
\end{abstract}

The PNW is endowed with extensive water resources infrastructure and well-established and well-funded management agencies responsible for ensuring that water resources objectives (such as water supply, water quality, flood control, hydropower production, environmental services, etc.) are met. Likewise, access to observed hydrological, meteorological, and climatic data and forecasts is in general exceptionally good in the United States and Canada, and is often supported by federally funded programs that ensure that these resources are freely available to water resources practitioners, policy makers, and the general public.

Access to these extensive resources support the argument that at a technical level the PNW has high capacity to deal with the potential impacts of natural climate variability on water resources. To the extent that climate change will manifest itself as moderate changes in variability

Correspondence to: A. F. Hamlet

(hamleaf@uw.edu) or extremes, we argue that existing water resources infrastructure and institutional arrangements provide a reasonably solid foundation for coping with climate change impacts, and that the mandates of existing water resources policy and water resources management institutions are at least consistent with the fundamental objectives of climate change adaptation. A deeper inquiry into the underlying nature of PNW water resources systems, however, reveals significant and persistent obstacles to climate change adaptation, which will need to be overcome if effective use of the region's extensive water resources management capacity can be brought to bear on this problem. Primary obstacles include assumptions of stationarity as the fundamental basis of water resources system design, entrenched use of historical records as the sole basis for planning, problems related to the relatively short time scale of planning, lack of familiarity with climate science and models, downscaling procedures, and hydrologic models, limited access to climate change scenarios and hydrologic products for specific water systems, and rigid water allocation and water resources operating rules that effectively block adaptive response. Institutional barriers include systematic loss of technical capacity in many water resources agencies following the dam building era, jurisdictional fragmentation affecting response to drought, disconnections between water policy and practice, and entrenched bureaucratic resistance to change in many water management agencies. These factors, combined with a federal agenda to block climate change policy in the US during the Bush administration have (with some exceptions) contributed to widespread institutional "gridlock" in the PNW over the last decade or so despite a growing awareness of climate change as a significant threat to water management. In the last several years, however, significant progress has been made in surmounting some of these obstacles, and the region's water resources agencies at all levels of governance are making progress in addressing the fundamental challenges inherent in adapting to climate change.

Published by Copernicus Publications on behalf of the European Geosciences Union. 


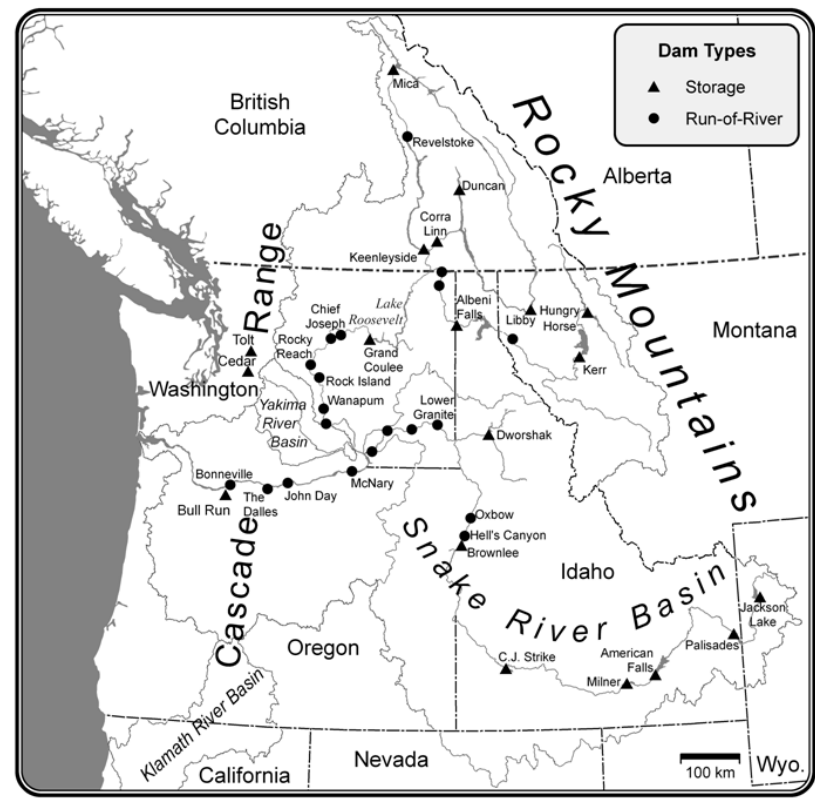

Fig. 1. Map of the Pacific Northwest including the Columbia River basin and Coastal Drainages in WA and OR. Major dams in the Columbia and selected projects and geographic features discussed in the text are shown.

\section{Introduction and background}

The Pacific Northwest Region of North America (Fig. 1) is comprised of a diverse set of landscape characteristics which are strongly related to topography and proximity to the coast. The domain we consider in this paper encompasses the Columbia River basin (CRB), and coastal watersheds in the states of Washington and Oregon. Much of the hydrologically significant precipitation in the region occurs in cool season (October-March), which in colder, snowmelt-dominant watersheds is mostly stored as snowpack, effectively transferring water availability from cool season to warm season (April-September) (Hamlet, 2003). In portions of the region with relatively warm winter temperatures (mostly near the coast), water availability is either winter dominant (essentially following seasonal precipitation patterns in rain dominant systems) or has two peaks, one in the fall related to runoff production associated with a mix of rain and snowmelt.

\subsection{Climate change scenarios for the Pacific Northwest}

Climate change projections for the PNW, from global climate model (GCM) scenarios from the Intergovernmental Panel on Climate Change (IPCC) Fourth Assessment Report (AR4) are shown in Fig. 2 for two emissions scenarios: A1B (a medium-high emissions scenario), and B1 (a low emissions scenario) (Mote and Salathé, 2010).

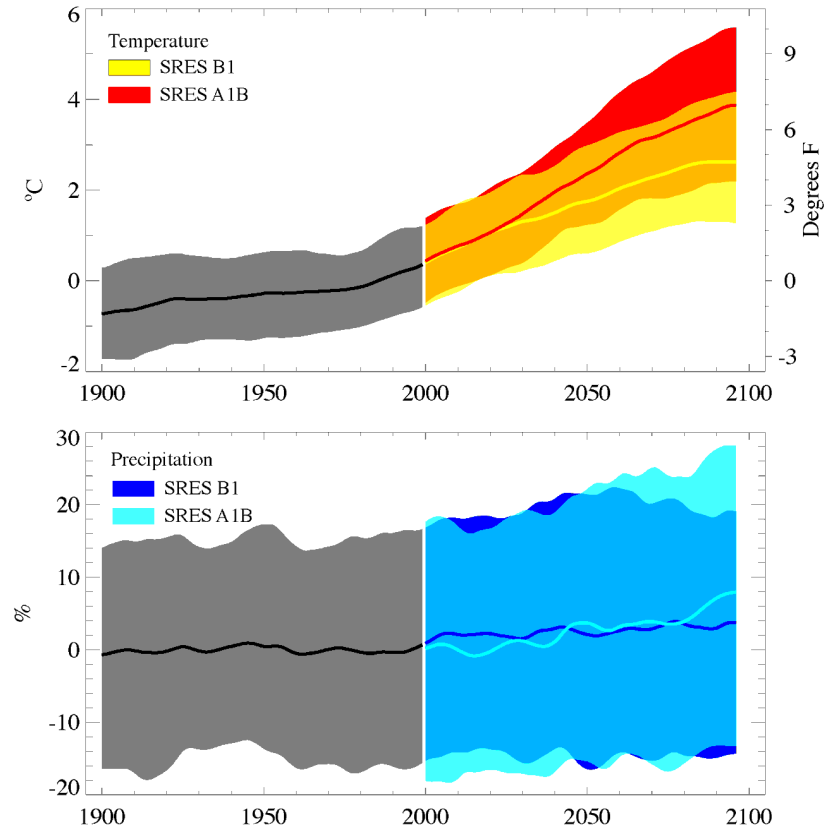

Fig. 2. Summary of 20th and 21 st century annual temperature and precipitation simulations from $20 \mathrm{GCMs}$ over the PNW for two greenhouse gas emissions scenarios. Solid lines show the mean. The grey bands show the range (5th to 95 th percentile) for the historical simulations, the colored bands show the range of future projections for each emissions scenario. Source: Mote and Salathé (2010).

The effects on regional temperature show a very high signal to noise ratio, meaning that the systematic changes in temperature are very large in comparison with the observed range of variability. For example, by the $2040 \mathrm{~s}$ the new 5 th percentile value is close to the 95th percentile shown for the second half of the 20th century. These projections show that we are very likely to enter uncharted territory for high temperatures in the future, and that cooler temperatures which were commonly encountered in the historical record are likely to become increasingly infrequent events.

The effect of different emissions scenarios on the results show strong differences at the end of the 21st century (almost twice as much warming for A1B as for B1), whereas by mid century the results for the two different emissions scenarios are remarkably similar. These findings show that reductions in greenhouse gas emissions will likely play a very important role in reducing impacts in the long term (a century), while in the shorter-term (several decades) little reduction in warming can be expected, and adaptation to impacts that are "already in the pipeline" may be the only viable approach to reducing undesirable outcomes associated with climate change.

For annual precipitation, a very different picture emerges. The GCM simulations show a very low signal to noise ratio, meaning that the systematic changes are small relative to the range of observed variability. For the PNW as a whole, there 
are relatively small changes in annual precipitation, and the range of normal variations that occur from decade to decade (e.g. those associated historically with the Pacific Decadal Oscillation) will probably play a very important role in determining the actual outcomes related to precipitation in any future decade. The effects of different emissions scenarios on precipitation are likewise very modest (compare A1B to B1 at the end of the 21st century, for example). Although systematic changes in annual precipitation are small, many GCMs show systematic increases in winter, spring, and fall precipitation and decreases in summer precipitation, which have some important implications for a number of impact pathways in the PNW (e.g. winter flooding, summer low flows, fire)

It should be noted that changes in precipitation simulated by GCMs are generally much more uncertain than changes in temperature, and greater caution must be exercised in interpreting precipitation results. Another way to say this is that we should expect more potential "surprises" in the effects of global climate change on PNW precipitation than we should for temperature.

\subsection{Hydrologic impacts of climate change}

Figure 3 shows a map of the ratio of peak snow water equivalent (SWE) to cool season precipitation (a measure of the importance of snow to the hydrologic cycle) for historical conditions and future scenarios. Overall the changes in hydrology can be characterized by a landscape-scale transformation from snowmelt dominant and mixed rain and snow basins to rain dominant behavior. Some areas, however, and most notably the portion of the CRB in Canada, remain strongly snowmelt dominant.

In both mixed rain and snow and snowmelt-dominant basins, loss of snowpack due to warming, and generally increasing winter precipitation, in the scenarios increase winter flow, while summer flow declines (Fig. 4a and b) (Elsner et al., 2010). In rain dominant basins there is little shift in the seasonality of flow, and runoff volumes largely follow changes in precipitation in cool season (Fig. 4c). Increases in evaporation combined with relatively small positive changes in cool season precipitation tend to result in small changes (positive or negative) in annual flows (Elsner et al., 2010). These hydrologic impacts have many water resources implications in the PNW including impacts to water supply (Vano et al., 2010a, b), flood control (Payne et al., 2004; Lee et al., 2009, 2010), hydropower production (Hamlet et al., 2010), and environmental services (Mantua et al., 2010).

Increases in hydrologic extremes are a complex function of the seasonality of changing precipitation in the scenarios and effects to effective basin area and antecedent snow related to warming. Figure 5, for example, shows changes in flood risk over the PNW for three future time periods and two emissions scenarios (A1B and B1). Relatively warm basins near the coast and in moderate elevation areas on the west
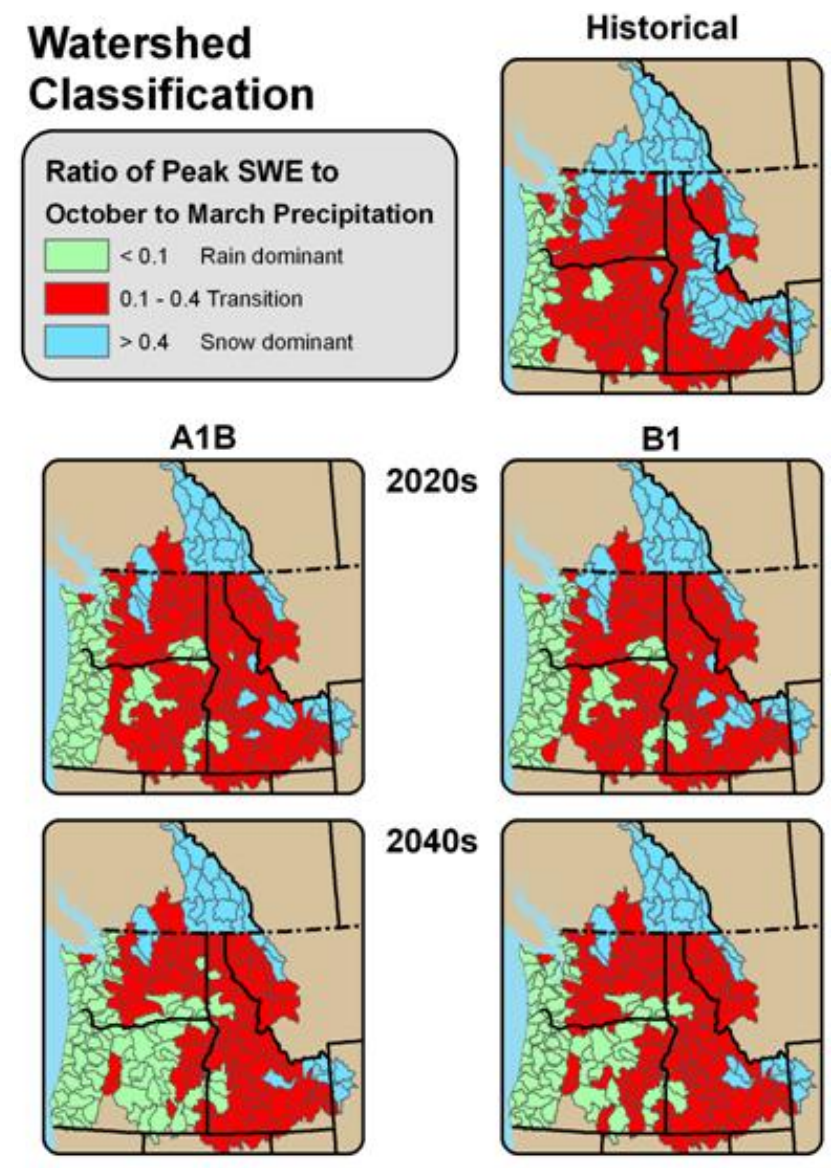

2040s

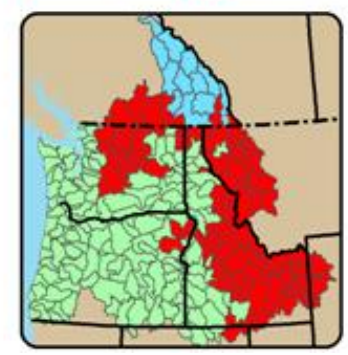

2080s

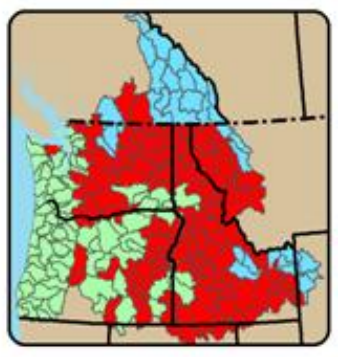

Fig. 3. Simulated changes in the fraction of cool season precipitation stored as peak snow water equivalent (a measure of basin hydrologic response). Basins at the 8-digit (4th level) HUC scale are characterized as rain dominant $(<0.1)$, mixed rain and snow ( 0.1 to 0.4 ), or snowmelt dominant $(>0.4)$ for historical conditions and six composite delta method climate change scenarios. Source: Tohver and Hamlet (2010).

slopes of the Rocky Mountains (e.g. in Idaho and Montana) tend to show higher flood risk due to increasing cool season precipitation and the increasing effective basin area that accompanies rising snow lines, whereas colder basins in the interior and northern parts of the region show small changes (or even decreasing flood risk) in spring due to systematic loss of snowpack (Hamlet and Lettemaier, 2007). Low lying, rain dominant basins show modest increases in flood risk associated with increased winter precipitation (Mantua et al., 

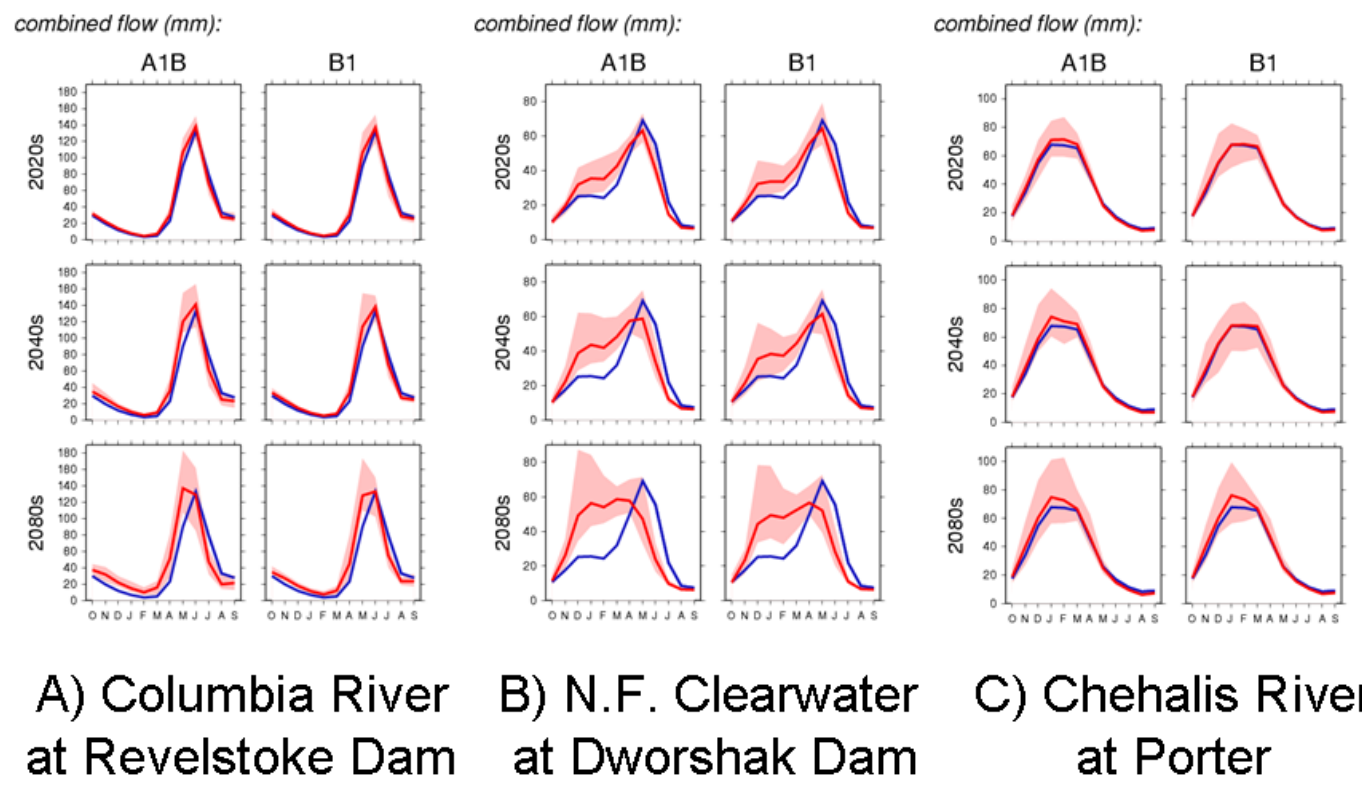

\section{A) Columbia River B) N.F. Clearwater C) Chehalis River at Porter}

Fig. 4. Monthly average runoff simulations for three PNW watersheds for three future time periods and emissions scenarios, (A) the Columbia River at Revelstoke Dam, (B) the N. F. Clearwater at Dworshak Dam, (C) the Chehalis River at Porter. Blue lines show the monthly runoff for the 20th century climate (1916-2006), the pink bands show the range of the 10 hybrid delta climate change scenarios (based on the IPCC AR4), and the dark red line shows the average of the hybrid delta ensemble. Source: Columbia Basin Climate Change Scenarios Project: http://www.hydro.washington.edu/2860/.

2010; Tohver and Hamlet 2010), but are relatively insensitive to warming. Water quality, and particularly water temperature (Mantua et al., 2010) and turbidity are also expected to be impacted by warming and precipitation changes.

\section{Overview of PNW water resources systems and their historical development}

The Columbia River basin (CRB) is the dominant water resources system in the PNW, and is one of the most extensively developed hydropower systems in the world. The CRB encompasses most of Oregon (OR), Washington (WA), and Idaho (ID) in the US and about $30 \%$ of the basin area is in southern British Columbia (BC) in Canada. On average the CRB supplies about $70 \%$ of the PNW's electrical demand, and produces about $30 \%$ of the total hydropower in the US. Historical development and current water resources policy in the CRB has been strongly influenced by international agreements between the US and Canada, most notably the Columbia River Treaty (1964), which created the conjunctive hydropower and flood control policies that constitute the fundamental basis of the Columbia's reservoir operations (Hamlet, 2003). More recently, however, endangered species listings of a number of salmon species in the $\mathrm{CRB}$ and associated protection and restoration efforts in the basin have had a significant impact on water policy and dam operations in the CRB (BPA, 1994). Water supply for irrigation is also an important water resources objective in several sub-basins of the CRB, most notably the Snake River basin (primarily in Idaho), the Yakima River basin,the Central Columbia basin in Washington State (WA), and the transboundary Okanagon/Okanagan basin in British Columbia and WA. The CRB is largely governed by federal water management agencies such as the Bonneville Power Administration (federal hydropower marketing), the US Army Corps of Engineers (flood control), the US Bureau of Reclamation (water supply for irrigation), National Marine Fisheries Service (NMFS) (salmon protection and restoration). Institutional arrangements in Canada are similar, with BC Hydro managing the province's hydropower resources and coordinated flood control operations, and various groups within Environment Canada and the Provincial government managing other aspects of water resources management. Miles et al. (2000) noted that centralized decision makers and wellcoordinated management systems have emerged historically for flood control and hydropower, whereas management systems impacted by low flows are much more diffuse and lack a central decision making body. One explanation for the difference in these two management communities is that the Columbia River Treaty imposed a centralized management structure associated with its primary objectives (flood control and hydropower), whereas the development of management systems cope with low flow impacts has occurred historically at a more local scale over a longer period of time, resulting in greater fragmentation (see Sects. 6 and 7.2 for additional discussion of the implications of these institutional characteristics). 


\section{Ratio of 100-year Flood Statistics}

(21st Century $\div$ 20th Century)

A1B
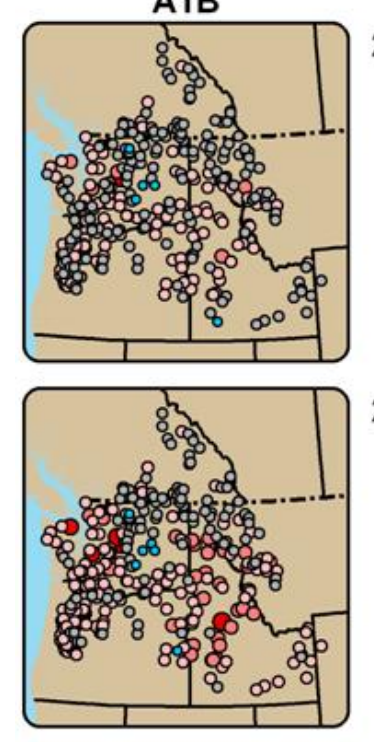

2040s

2020s
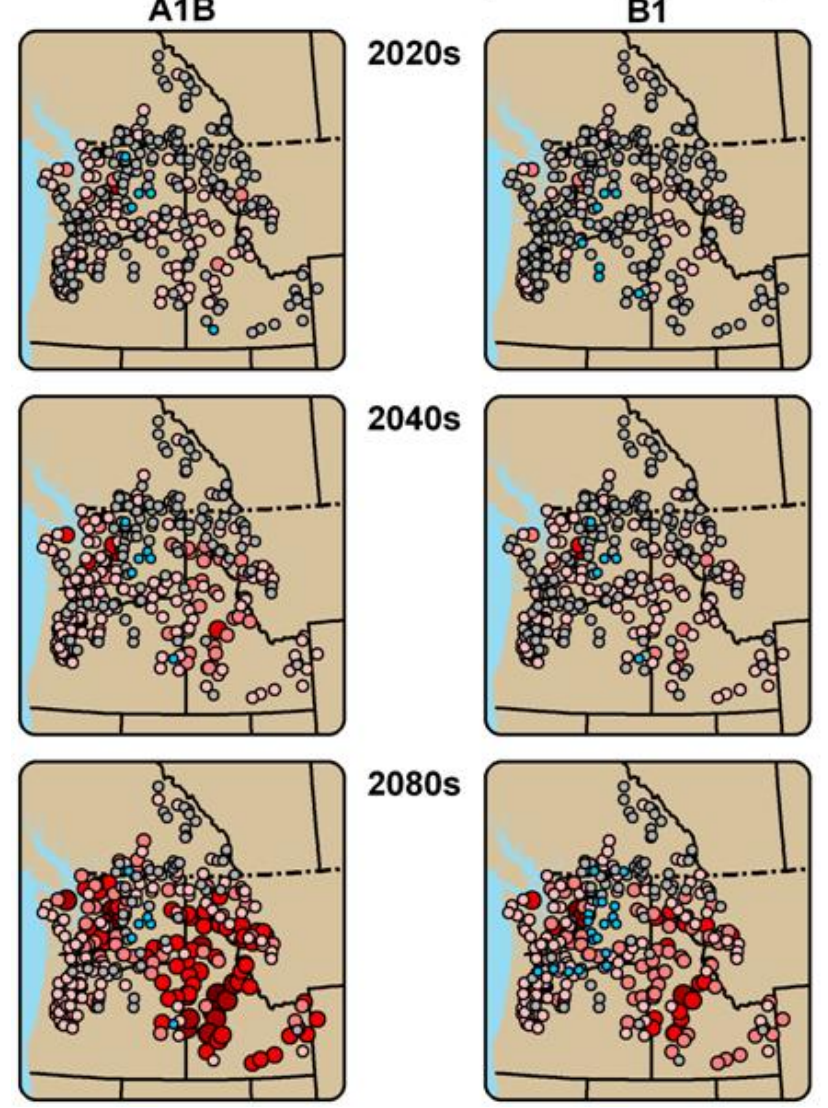

2080s
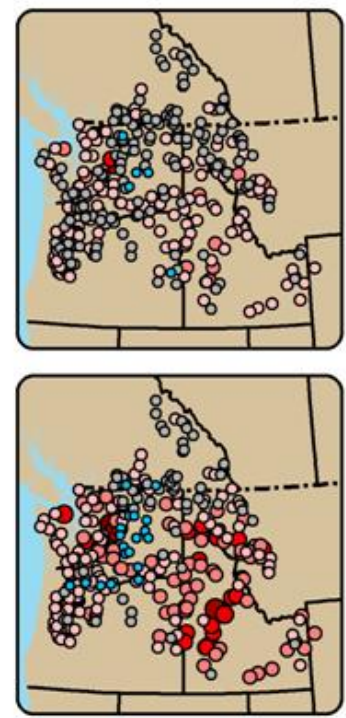

Fig. 5. Maps of the ratio (future/historical) of the 100-yr flood magnitude for three future time intervals, under two scenarios for a 297 river locations in the PNW. (Higher ratios indicate more intense flooding events projected for the future). Source: Tohver and Hamlet (2010).

In addition to the CRB, a large number of sub-regional to local-scale water resources systems have developed in the PNW. Many of these are designed to provide water for irrigated agriculture or urban water supply (Fig. 1). In western WA and OR, for example, a number of small watersheds on the west slopes of the Cascades provide drinking water for the region's largest urban populations (e.g. in the Vancouver, Seattle, and Portland metro areas). These systems are typically operated by local utilities. Irrigated agriculture is usually the largest consumptive water use in many smaller watersheds east of the Cascades (Vano et al., 2010b). These smaller water supply systems are typically managed by local irrigation districts in collaboration with federal water management agencies such as the US Bureau of Reclamation.

Given the importance of PNW ecosystems to the regional economy, it is a surprise to many that ecosystem considerations were, historically, almost entirely missing from the design of most water resources systems in the PNW. In fact it is only in the last several decades that water resources managers have been required to significantly incorporate the functioning and health of ecosystems as part of their management strategies (Cohen et al., 2000). A huge shift in social values has taken place over the 20th century. At the time Grand Coulee Dam was built in the late 1930s, for example, the idea of blocking all of the anadromous fish runs above the dam (encompassing the entire upper Columbia River basin - Fig. 1) was not even considered an issue of serious concern. Today such a perspective (and arguably the building of the dam itself) would be unthinkable.

While awareness of protection and enhancement of ecosystems as an important water resources objective has been a relatively recent addition to the PNW's water management culture, it is worth noting that some of the oldest water rights (and therefore the most senior) are held by PNW Native American Tribes. These rights are often tied either directly or indirectly to protection of fishing and hunting rights guaranteed by treaties established in the mid-19th century. In this sense, the importance of ecosystems has been acknowledged by legal agreements for a long time. At the same time, it is hard to argue that Native American treaty rights were a significant factor informing water resources development in the 20th century, because the existing treaties were completely ineffective in stopping water resources development that intentionally ignored these long-standing obligations. The construction of Grand Coulee Dam, for example, destroyed the salmon fishery upon which the Colville Tribe in eastern WA depended, and flooded tribal lands. Despite the Colville Tribe's treaty rights, meaningful compensation for these devastating environmental, cultural, and economic impacts did not take place until the 1990s, nearly $60 \mathrm{yr}$ later (http://www.ccrh.org/comm/river/docs/coltest3.htm).

\section{Western water law and water allocation policies}

Water allocation policies in western North America, and associated water law, are fundamentally based on the 19th century Prior Appropriations Doctrine ("first in time, first in right") and legal requirements for ongoing "beneficial" use of water ("use it or lose it"). Historically, beneficial use of water has been strongly linked to the economically beneficial use of water (e.g. urban water supply, agriculture, mining, hydropower production, industrial uses, etc.). In recent years the use of water for ecosystem services (e.g. instream flow for fish) has become an increasingly high priority. A water right is typically associated with the land (particularly in the case of irrigated agriculture), the specific use of water, and the water's source, although these can be changed under the law without relinquishing the water right itself. The holder of a water right can accept direct compensation for a transfer of right to another water user; thus the water right can 
be effectively be "sold", despite the fact that the water right holder does not actually own the water itself.

While these principles define an overarching institutional structure, there are subtle differences in the way the laws and institutional principles have been applied in different States in the US, and in Canada. In the US the ownership of the water by the government is arguably somewhat less clearly defined than it is in Canada. For example, although a water right holder in either the US or Canada does not technically own the water itself, in the US the government does not have the right to unilaterally revoke water rights without compensation (i.e. the courts have ruled that such an action would constitute a takings) (Slaughter et al., 2010).

Different States also have differing definitions of "beneficial use" of water. Instream flow for fish, for example, is not formally recognized as a beneficial use of water in the State of Idaho, whereas it is in the State of Washington. Thus the existing structure of water law can be a potential obstacle to the transfer of water rights between different uses. Jurisdictional problems are also apparent. Water flowing across a state or international boundary, for example, may be recognized as beneficial to the region receiving the flow (e.g. in supporting beneficial use of water for instream flow in WA), but not to the region from which the water flows (e.g. from Idaho).

\section{Supporting services for PNW Water Managers}

Waterresources management in the US and Canada is supported by extensive services for monitoring and predicting river flow. The US Geological Survey (USGS) (http: //water.usgs.gov/) has primary responsibility for the US's stream gaging network, and provides free access on the internet to both real-time and historical records. Environment Canada supports a similar system in Canada (http://www.ec. gc.ca/rhc-wsc/default.asp?lang=En\&n=4EED50F1-1). Similarly, historical meteorological and climatological data is available in the US from the National Climatic Data Center (NCDC) (http://www.ncdc.noaa.gov/oa/ncdc.html) and in Canada from Environment Canada (http://www. climate.weatheroffice.gc.ca/Welcome_e.html). Additional historical climate data and climate forecasts are available from NOAA's Climate Prediction Center (CPC) (http:// www.cpc.noaa.gov/) and Environment Canada (http://www. weatheroffice.gc.ca/saisons/index_e.html). Seasonal forecasts of river flow are provided to water resources managers by groups like the National Resources Conservation Service (NRCS)(http://www.nrcs.usda.gov/feature/ highlights/SnoServ.html), which also supports a large network of automated snowpack measurement sites (SNOTEL) (http://www.wcc.nrcs.usda.gov/snow/). Similar products are available in Canada from Environment Canada (http://www. env.gov.bc.ca/rfc/data/). The Pacific Northwest River Forecast Center (http://www.nwrfc.noaa.gov/) also provides a range of streamflow forecasting products, using both statistical approaches (regression equations) and ensemble streamflow prediction (ESP) methods using semi-distributed hydrologic models. Water managers also have access to quantitative flood forecasts based on weather forecasts provided by NOAA in the US (http://www.nwrfc.noaa.gov/) and Environment Canada (http://www.ec.gc.ca/eau-water/default. asp?lang=En\&n=7BF9B012-1), and these hydrologic forecasts feed flood warning systems that communicate these risks to emergency managers and the public. Individual water resources agencies also produce hydrologic forecasts or hire private-sector consultants to provide these products. Drought monitoring and prediction services are available in the US from the National Integrated Drought Information System (NIDIS) (http://www.drought.gov/portal/server. pt/community/drought_gov/202) and NOAA's North American Drought Monitor (http://www.ncdc.noaa.gov/oa/climate/ monitoring/drought/nadm/). These kinds of services provide an extensive set of resources to water managers for coping with climate variability and hydrologic extremes. (It is worth noting that widespread access to the world wide web in North America has completely transformed the level of access to these kinds of data and services in the last $15 \mathrm{yr}$.)

Although primarily supported by academic research programs at present, a wide range of climate services including detailed hydrologic scenarios are also available to PNW water managers. Groups providing these services in the PNW include the Climate Impacts Group in the PNW (http: //cses.washington.edu/cig/) and the Pacific Climate Impacts Consortium in BC (http://pacificclimate.org/). As an example of the kinds of climate change data resources that are now being generated, a recent three year project conducted by the Climate Impacts Group and a group of regional stakeholders has generated a comprehensive set of hydrologic scenarios to support water resources planning in the PNW (http://www.hydro.washington.edu/2860/). A number of more local-scale groups, such as the Oregon Climate Change Research Initiate (OCCRI) (http://occri.net/), and a consortium of universities in OR, WA, and ID (http:// www.webs.uidaho.edu/epscor/) have recently formed to provide additional climate services and stakeholder support at the sub-regional scale. Some of these groups also participate in west-wide climate change assessment activities in the US via collaborative projects with similar groups in California and the Southwestern US.

\section{Overview of traditional water planning processes in the PNW}

Until very recently, formal water resources planning in the US and Canada has been based almost exclusively on the use of observed streamflow records. These approaches implicitly assume a stationary climate system, and attempt to construct (and test, e.g. via simulation) water resources systems that 
are relatively robust to the observed climate variability represented by observed streamflow records. By extension, these well-tested systems are assumed to be relatively robust to future climate variability. Similar approaches are used to characterize the risk of extreme events. For example, estimates of the "100-yr flood" (a flood event with an estimated 1\% probability of occurrence in any one year) are typically based on the analysis of observed streamflow records (Stedinger et al., 2003). Projections of changing population, water or energy demand, or other factors related to water resources system performance are commonly incorporated in planning studies, but systematic changes (or for that matter even decadal scale variations) in climate that affect hydrologic extremes are not typically considered in planning.

There are significant institutional and practical problems related to disconnections between the traditional timescale of water planning ( $\sim 20-30 \mathrm{yr})$, and the timescale of analysis needed to inform sustainable resource management decisions in the context of climate change. In particular, planning horizons for water resources studies are too short to address the sustainability issues associated with population and hydrologic changes that are anticipated near the end of the $21 \mathrm{st}$ century. These problems are exacerbated by practical time scales associated with policy making, which are affected by political cycles which are of even shorter duration than those associated with traditional water planning. During the most recent Bush administration in the US (2000-2008), for example, climate change assessment, greenhouse gas mitigation policies, and climate change adaptation efforts at the federal level were all but brought to a standstill. In the first several years of the Obama administration, rapid progress has been made in bringing federal resources to bear on these important problems. However, neither administration has institutionalized a viable framework for sustainable water planning, because the fundamental time scale of change in the political environments that affect these decisions has not been altered.

These issues related to the time scales of planning and political cycles that affect policy are extremely important because policy decisions related to water infrastructure and/or water allocation are generally very difficult, if not impossible, to reverse. Allocation of water to particular stakeholders for economic development, for example, typically results in private investment by these stakeholders. Regulatory actions that attempt to retract these water allocations in response to altered future conditions, therefore tend to create contentious struggles over property rights (Slaughter et al., 2010). The many difficulties encountered in the PNW in attempting to remove existing dams in response to changing environmental values highlights the need for new ways to approach the sustainability of infrastructure and water allocation choices in light of a non-stationary climate.

The need for new technical approaches to water planning has also become apparent. Some academic studies have attempted to explore alternative methods for water resources planning using optimization rather than simulation
(Labadie, 2004; Lund and Ferreira, 1996; Lee et al., 2009, 2010; Medellin-Azuara et al., 2008), but such techniques are rarely applied in formal long-term (meaning more than a year ahead) planning studies conducted by water resources management agencies. The reasons for the choice of simulation as the dominant planning approach are complex, but are partly related to the fact that optimization results are frequently difficult to interpret in the context of highly constrained systems governed by a large number of regulatory requirements. In addition, skillful long-term forecasts of future streamflows have not historically been available to planners, a situation which limits the practical utility of optimization. Optimization, when it is employed in water management at all, is commonly used only at very short lead times of a few days (e.g. in optimizing short-term hydropower operations in response to weather forecasts). As discussed in more detail below, attempts to identify effective adaptation strategies in response to climate change may ultimately provide a more important role for optimization in long-term water planning in the future.

\section{Institutional issues}

Institutional constraints play an important role in determining the ability of PNW water resources management systems to adapt to climate variability and climate change. As introduced in Sect. 2, Miles et al. (2000) demonstrated that the ability to respond effectively to drought impacts (and by extension climate change impacts) in the CRB was impaired by institutional fragmentation, lack of centralized authority, and conflicted management objectives in times of water scarcity. By comparison, centralized management systems associated with flood control and hydropower production in the CRB were much more robust, due to well-established institutional roles, centralized management authority, and carefully coordinated conjunctive management objectives (see also Sect. 7.2.).

Likewise, wide-spread adherence to rigid 19th century water laws and inflexible institutional arrangements associated with water allocation (Sect. 3) can be important barriers to adaptative actions that seek to increase flexibility in managing water supply and demand (Slaughter and Wiener, 2007; Slaughter, 2009). Despite these potential concerns, major changes in the fundamental structure of these arrangements seems very unlikely due to the sociopolitical intractability of such changes. In the Yakima River basin, for example, a court ordered adjudication of existing water rights (i.e. a formal documentation of all existing water rights and their relative priority) has taken more than $30 \mathrm{yr}$ to complete. Having engaged in such an exhausting effort to affirm and stabilize the existing system of water rights, it seems unlikely that sufficient political will could be generated to replace this existing system with another (and inherently less well proven) alternative. 
A greater willingness to deviate from current practice has been apparent, however, in attempts to increase flexibility in the transfer of water between users in response to drought, using, for example, water markets or water banks (Fereday et al., 2009; WDOE, 2004). Such approaches have been tried with some success in recent decades in Idaho (Slaughter, 2009). One explanation for the apparently greater willingness to consider changes in water law related to water transfers is that there is a potential economic benefit to individual water rights holders associated with the transfer water in times of shortage; whereas such benefits are not obvious in a shift to a fundamentally revised water allocation system.

Taken together, this historical experience suggests that the Prior Appropriations Doctrine will probably remain in place as the foundation of western water law, but that attempts to increase flexibility in times of shortfall may follow increased water stress. Such approaches to climate change adaptation are also probably "no-regrets" strategies since drought is already a significant management issue. As discussed below, the sale of water rights as real property is another way of transferring water between users or uses in response to changing water availability, and such transfers do not require a change in existing law, except in the case where the proposed future use is prohibited by current law (e.g. not classified as "beneficial" use). This caveat applies to some kinds of water transfers from water supply to instream flow in support of ecosystem services, which are not always recognized as "beneficial" use. Large, complex water systems are arguably less flexible than their simpler, local-scale counterparts because of bureaucratic constraints that are obstacles to change. Gray (1999), for example, showed that the relatively small and autonomous Seattle Water Supply System was able to incorporate new information about climate variability into its operations much more rapidly than the larger, more institutionally complex, and more bureaucratically entrenched system in place in the Yakima River basin in Eastern WA. Likewise, the dramatic increase in complexity of the Columbia River basin's operating policies over the last $50 \mathrm{yr}$ or so has been identified as an important obstacle to climate change adaptation because of the difficulty and cost of evaluating the integrated effects of increasing population, hydrologic changes, and other factors on a wide array of interconnected management objectives (Cohen et al., 2003)

Historical perspectives and experience also play an important role in informing adaptive capacity to climate variability and climate change. Slaughter et al. (2007), for example, argued that management systems in the Snake River basin (located in the arid southeastern corner of the Columbia basin) were much more robust to drought impacts than the Klamath River basin in southern OR and northern CA largely because severe droughts were a common occurrence in the Snake basin, whereas, until a severe water supply crisis occurred in 2001, water shortages had rarely (if ever) been experienced historically in the Klamath basin. Thus historical conditions in the Snake basin resulted in management systems that were informed by well-established, well-coordinated, and frequently exercised management plans designed to cope with drought, whereas in the Klamath basin an unprecedented drought in 2001 resulted in serious impacts to stakeholders because these institutional arrangements had not been established. A common assumption is that water scarcity is a good indicator of vulnerability to future increases in drought stress. This case study shows that the opposite may be true.

Loss of certain kinds of technical capacity in water management agencies, and/or emergence of new needs related to climate change adaptation outside the current technical capacity of most water management professionals has also been identified as a significant issue informing adaptive capacity. Following the dam building era (which effectively ended in about 1975 in the PNW), many large water management agencies shifted their focus from water resources engineering and the building of physical structures to the long-term management of existing water resources systems and infrastructure. Staff who were capable of designing or revising reservoir operating policies were largely eliminated from many water resources management agencies over time because these services were not perceived to be needed in the new era. As a result, it is common to find reservoir operating policies dating from the time of dam construction with little meaningful change in the intervening time. Analyzing climate change impacts on water resources requires expertise in a number of different disciplines including atmospheric sciences (e.g. climate modeling, downscaling procedures) hydrology (specifically physically based hydrologic modeling), and systems engineering (e.g. reservoir simulation/optimization modeling). Of these, only reservoir simulation modeling expertise using historical streamflows is typically present in most water management agencies. This situation supports the argument that many water management agencies are currently most effective as "caretakers" of the systems they currently manage, as opposed to "innovators" who can respond quickly to potentially changing needs associated with climate change. It is worth noting, however, that this situation has been changing rapidly over the last five years or so, and investments in technical capacity in these specific areas has been growing. BC Hydro, to cite one example, has invested $\$ 800 \mathrm{k}$ over the last four years in establishing a collaborative long-term relationship with the Pacific Climate Impacts Consortium specifically to increase technical capacity and address climate change impacts. The US Bureau of Reclamation has been investing heavily in agency-wide attempts to increase technical capacity related to climate change planning and adaptation. Similarly, well-organized collaborative efforts between the Climate Impacts Group at the University of Washington, the Bonneville Power Administration, the Northwest Power and Conservation Council, the US Bureau of Reclamation, the US Army Corps of Engineers, and other state and federal agencies are currently in progress in the PNW. 


\section{Prospects for water resources adaptation in the PNW}

At face value, the availability of infrastructure and welldeveloped support services (discussed above) supports the argument that PNW water management systems have a relatively high capacity to deal with climate variability. To the extent that climate change results in modest changes in variability, one can legitimately argue that adaptive capacity to climate change and existing capacity to deal with climate variability are probably not very different. Some water resources practitioners, for example, have argued that adapting to climate change does not require special actions on the part of water management agencies because these agencies are already charged with ensuring that the performance of these systems in meeting water resources objectives is maintained over time, and already have effective tools in place to deal with these matters. Eugene Stakhiv of the Institute for Water Resources, commenting on climate change adaptation, wrote: "Notwithstanding the difficulties of anticipating and responding to the ill-defined impacts of global warming, particularly in its various hydrological manifestations, a case can be made that the water resources management community need not take any extraordinary precautions because they already practice or have at their disposal most of the measures and analytical tools that are being prescribed to anticipate or respond to the postulated adverse impacts of global warming." (Stakhiv, 1993).

\subsection{Evidence of autonomous adaptation capacity in the PNW}

Although perhaps overly reductionist in tone, Stakhiv's argument is broadly supported by recent management experience in several PNW water supply systems. The response of Seattle Public Utilities (which manages Seattle's water supply system - see Cedar and Tolt reservoirs in Fig. 1) to increasing drought risk over time is a good example of autonomous adaptation to climate change. Although historical impacts to the hydrology of watersheds on the western slopes of the Washington Cascades (which supply Seattle's water) are only partly attributable to greenhouse forced climate change (Mote et al., 2005, 2008), nonetheless these watersheds have already experienced changes in climate and hydrologic variability that are comparable in magnitude to projections of climate change for the 21st century. Observed losses of 1 April snow water equivalent (SWE) in the Cascades from 1950 to the mid 1990s, for example, have been on the order of 1535\% (Mote et al., 2005, 2008), which are comparable in magnitude to mid-21st century projections of snowpack loss in the Cascades (Elsner et al., 2010). While it is true that Seattle Public Utilities did experience increased difficulty in managing the water supply during several years at the end of the 20th century (e.g. during severe droughts in the El Niño water years 1987-1988 and 1991-1992), it would be misleading to describe the utility as unable to respond effectively to these changes. In fact, there is considerable evidence that the utility learned from these adverse experiences (Gray, 1999), and has increased its capacity to respond to drought during El Niño years, effectively avoiding water supply impacts due to similar low snowpack conditions in 2004-2005 and 20062007. Similarly, Seattle Public Utilities has demonstrated exceptional ability to achieve conservation goals. Despite an increase in population, actual water demand in Seattle is currently at approximately 1970 levels. Although reductions in available water supply of about $15 \%$ are anticipated for the Seattle System by mid 21st century due to projected reductions in snowpack and summer streamflow (Wiley, 2004), these reductions in yield seem well within the reach of ongoing demand management strategies, particularly since Seattle is not using all of its available capacity under current conditions. A later study by Vano et al. (2010a) corroborates these findings.

As introduced above, a similar argument can be made for several other PNW water resources management systems with well-established institutional arrangements designed to cope with drought. In Idaho, for example, more than $99 \%$ of the consumptive water use is associated with irrigated agriculture, and a well-defined water allocation system establishing the priority of different water rights holders is combined with an extensive water management system designed to align demand with supply. When an unprecedented fiveyear drought emerged at the end of the 20th century causing documented impacts to the sustainability of groundwater and surface water resources, a \$26 million state-funded buyout of water rights by the ID Dept of Water Resources occurred in 2008 in an attempt to realign long-term demand with available water supplies. As in the case of Seattle Public Utilities discussed above, there was no direct evidence that the drought that caused this management response was caused by global climate change, yet the system responded autonomously to the observed change in supply based on management objectives already in place. This response supports the argument that if climate change projections of reduced summer water supply in Idaho prove accurate, the current management framework may be sufficient to adapt to changing conditions as they emerge in real time.

Technological responses to water shortage are another kind of adaptive response that can happen largely autonomously via choices made by individual stakeholders. For example, in Idaho, there is evidence that farmers have responded autonomously to increasing water shortage over the last several decades by gradually installing more efficient irrigation technology, effectively avoiding serious impacts to crop production despite reduced overall water supply.

\subsection{Prospects for adaptation in large, institutionally complex systems}

While autonomous adaptation of the types discussed above seems very likely, a substantially different picture emerges 
when we begin to look closely at the prospects for climate change adaptation in larger and more institutionally complex water management systems. The Columbia River basin, the largest, most institutionally complex (and arguably the most important) water resources system in the PNW, provides an excellent case study for discussion of these issues.

The Columbia River water management system is inextricably linked to the PNW region's economy via hydropower production (on average supplying about $70 \%$ of the region's electrical energy), flood control, irrigated agriculture, navigation, and recreation. The Columbia also provides a huge range of ecosystem services to the region, many of which are linked (either directly or indirectly) to Native American culture and treaty rights (e.g. for hunting and fishing) in the basin. Attempts to mitigate ecosystem impacts associated with water resources development and other factors have focused primarily on the basin's endangered salmon populations, many of which are currently listed under the US Endangered Species Act (ESA). The basin is institutionally complex partly because of its size (covering most of WA, OR, and ID, and part of BC in Canada), but also because it is a transboundary watershed. The primary water management relationship between US and Canadian entities in the basin is governed by the Columbia River Treaty (CRT) of 1964. The CRT is fundamentally based on conjunctive management opportunities between winter hydropower production and flood control. The treaty facilitated the building of a number of large storage reservoirs in Canada (about $50 \%$ of the active reservoir storage is now in Canada), which, in concert with US projects, reduce flood risks and generate power. The hydropower produced by the Columbia's dams is primarily marketed by the Bonneville Power Administration in the US and by BC Hydro in Canada, although several Public Utility Districts own and operate individual dams in the system as well. Although relatively narrow in scope in comparison with the full array of management issues affecting the Columbia today (see discussion below), the CRT is widely viewed as one of the most successful and long-lived international water treaties in the world.

Miles et al. (2000) examined the Columbia basin's vulnerabilities to climate variability in different sectors and (by extension) evaluated its adaptive capacity to climate change impacts. As noted briefly above, the study found substantial differences in adaptive capacity to high flow impacts and low flow impacts. The Columbia basin management system responsible for flood control is highly centralized with wellestablished authority associated primarily with a single management entity (the US Army Corps of Engineers). Operational decisions for flood control are one of the highest priority system objectives and are also well integrated with basinwide hydropower operations. Under low flow conditions, by comparison, literally hundreds of individual management agencies must compete for a limited water supply. The complex interactions between these competing agencies that occur during droughts are in general poorly coordinated, and with the exception of large-scale hydropower production and well-coordinated irrigation systems in particular sub-basins of the Columbia (e.g. the Snake River basin in ID and the Yakima River basin in WA) lack a centralized decision maker with authority to act (Miles et al., 2000). These institutional characteristics are very important in the context of climate change adaptation, because the most severe climate change impacts in the Columbia are likely to be heavily weighted towards impacts to summer water supplies and to instream flow for fish rather than to high flow impacts (Hamlet and Lettenmaier, 1999). Thus the Columbia's poorly integrated management systems associated with low flow conditions imply a high vulnerability to increasing low flow impacts associated with climate change in warm season.

The institutional vulnerabilities discussed above are exacerbated by the extreme difficulty in achieving meaningful change in the Columbia basin's management system. Inertia in the Columbia's management system is evident in nearly every sector, but nowhere is it more evident than in the struggle to mitigate ecosystem impacts resulting from water resources development. Despite three decades of legally mandated effort to mitigate impacts to endangered salmon in the basin, there is no compelling evidence that conditions for the Columbia's endangered salmon populations have dramatically improved, and the reservoir management system, despite many modest changes at the margins (e.g. related to instream flow targets and habitat restoration), remains remarkably similar at its core to the operational policies established in the mid 1960s and 1970s by the CRT emphasizing hydropower production and flood control as the dominant management objectives (Miles et al., 2000). The reasons for the apparent inertia in the Columbia basin's water management policies are complex, widely debated, and a comprehensive discussion is well beyond the scope of this paper. An examination of some important factors, however, may help to generate some useful hypotheses for why the problem has historically been so intractable, and by extension why adapting to similar impacts associated with climate change may encounter similarly daunting obstacles.

To begin with the salmon life cycle is extraordinarily complex, and important salmon habitat ranges from small headwater streams to the open ocean, covering huge geographic areas. Decision processes that materially affect outcomes are associated with many levels of governance in two countries and multiple states in the US. Without a central decision making body (or even a common set of laws) to bridge these different scales, institutional fragmentation tends to determine the outcomes by effectively blocking meaningful action (Miles et al., 2000; Slaughter et al., 2010).

In addition to these factors relating to governance and institutional fragmentation, a comprehensive scientific understanding of the various factors associated with water management that may impact salmon are certainly broadly understood (e.g. ISAB, 2007), but authoritative statements regarding specific requirements for salmon 
survival often lack consensus in either the scientific or water management communities. Official Endangered Species Act (ESA) consultation documents submitted by NOAA Fisheries in the US (commonly referred to as the "Biological Opinion" http://www.nwr.noaa.gov/Salmon-Hydropower/ Columbia-Snake-Basin/Final-BOs.cfm) are routinely challenged in court after they are released (Columbia Basin Bulletin, 2009). These consultation documents also present a bewildering array of management areas requiring attention (e.g. listings of "reasonable and prudent alternatives") without prioritizing them or specifying how they would be achieved in practice. In reality only a few of these specific recommendations can be substantially addressed in a given period of time. Although management agencies are charged with responding to these recommendations, it is rarely clear how successfully meeting (or not meeting) a few of the hundreds of proposed action items listed would be expected to alter any measurable outcomes, or how important these specific actions are in relationship to other potential actions. This unfortunate lack of clarity in terms of priorities and measurable outcomes tends to undermine the will to act decisively on these recommendations, and also undercuts the ability to impose meaningful sanctions if specific management actions are ultimately not carried out by the water management community.

To cite one example, the role of instream flow on juvenile salmon survival is scientifically uncertain, and is clouded by other important factors such as loss of habitat in the Columbia River and estuary, effects of predation, competition between wild and hatchery fish, mortality due to structures such as dams and turbines, and natural variability or trends in conditions determining survival in the coastal and open ocean. Thus attempts to achieve target instream flow levels in spring and summer recommended by the Biological Opinion have been undermined by a lack of scientific consensus on how much such changes actually affect salmon survival. Water management agencies, faced with these uncertainties (and clear conflicts with what they view as their most fundamental, economically beneficial management objectives) have responded by either challenging these recommendations or by failing to allocate sufficient amounts of reservoir storage to fully meet these flow targets. As a result flow targets for fish passage are only infrequently fully met in practice (especially in late summer), and are especially vulnerable during droughts when reservoirs fall below storage cutoff levels associated with fish flow allocations. Thus the appearance of action (i.e. establishing a recommended flow target in support of juvenile fish migration) is not matched by an appropriate allocation of reservoir storage, or commensurate improvement in environmental conditions for fish in actual operations (Miles et al., 2000). Because the importance of flow for juvenile salmon survival is not clear at the outset, the implications of failing to meet these targets also cannot be clearly established and efforts to enforce the existing rules are further impaired in practice. Because the environmental flows are rarely fully met in practice, meaningful data regarding the benefits of fully achieving these target flow levels cannot be collected to help improve the science or refine these management strategies.

Another important issue in the context of future adaption to climate change impacts to salmon relates to the sheer number of regulatory requirements that water managers must address in the Columbia basin (Cohen et al., 2003). Historically, the many regulatory requirements relating to mainstem dam operations have been gradually built up over time, layer by layer. When the need for change is encountered, rather than attempt to peel back the many existing layers and make fundamental changes to the historical management framework, the tendency has been to leave the existing regulations in place (which are after all required by law) and add additional regulations at the margin to address the emerging concerns as well as possible. While, at first, such an approach avoids the many challenges of reversing past regulatory decisions, eventually such an approach results in a system that is so heavily constrained that all meaningful change is effectively prevented. There is considerable evidence that this "threshold of adaptability" has already been crossed in the case of the Columbia basin.

As mentioned above, the nature and root causes of the failure to successfully address salmon issues in the Columbia basin are hotly debated in the management community and in the courts, and consensus is frequently lacking. What seems clear, however, is that the current management system has been unable to generate meaningful change in response to widespread ecosystem impacts in the basin and clear cut legal mandates to address them (Miles et al., 2000). Whatever the root cause, this situation suggests very low adaptive capacity in this arena. This has important implications in the context of climate change, because serious ecosystem impacts related to loss of summer flow,increasing water temperature, and flooding are projected to emerge in the Columbia basin in the 21st century (Mantua et al., 2010; Hamlet et al., 2010). Hamlet et al. (2010), for example, showed that without operational changes, impacts to regulated summer flow in the ecologically important Hanford Reach of the Columbia River would become increasingly severe over the 21 st century. Mantua et al. (2010) demonstrated that wide-spread water temperature and low flow impacts across WA state due to warming and decreased summer precipitation will be a significant issue for PNW Salmon. Attempts to mitigate these impacts to instream flow and increasing water temperature in the main stem of the Columbia would likely require significant reallocation of reservoir storage and commensurate tradeoffs with winter hydropower production (Payne et al., 2004). Based on the management choices made in the last $30 \mathrm{yr}$ there is little evidence to support the hypothesis that such adaptive actions are likely to occur under the current management framework.

Another way to say this is that in a confrontation between traditional water resources objectives associated with 
direct and measurable economic benefits and management actions to provide ecosystem services of less tangible economic value, the current water resources management culture remains biased towards preservation of the former at the expense of the latter (Miles et al., 2000; Hamlet, 2003). Given these entrenched values within the management community, it remains unclear how such cultural and institutional biases (and the vulnerabilities they engender in responding to expected ecosystem impacts) might effectively be reduced.

Despite apparent gridlock over much of the Pacific Northwest on the salmon issue, in a few specific case studies more radical changes intended to recover salmon populations are being carried out. Perhaps most notable of these is the planned removal of two large dams on the Elwha River (in northern WA State) in the next several years. Removal of the dams will provide fish unimpeded access to extensive, pristine habitat in the upper basin. This is currently one of the largest dam removal projects in the country, and the outcomes of the project will provide crucial data on the rate of recovery of salmon populations following a major restoration of access to habitat. Removal of other large dams has been proposed throughout the region in response to the salmon crisis (perhaps most notably four large run-of-river dams in the lower Snake River in WA State). If dramatic and rapid increases in salmon productivity are observed in the Elwha case study, it seems likely that additional pressure in favor of other dam removal proposals will result. (It is worth noting that several smaller dams in the region, e.g. Marmot dam on the Sandy River in Oregon, have recently been removed specifically because the costs of mitigating ecological impacts outweighed the potential economic benefits of retaining the projects.)

Significant transboundary tensions are also likely to emerge in the Columbia basin in response to differential impacts of climate change in Canada and the US (Hamlet, 2003). Figure 3, for example, shows the transformation through time of the Columbia basin's snow resources due to regional warming. The spatial extent of snowmelt dominant and transient snow watersheds in the relatively warm US portions of the basin are dramatically reduced by mid21 st century, whereas in the colder Canadian portions of the basin, the hydrology is not as greatly affected, and remains snowmelt dominant even in the 2080s scenarios. Thus Canada is likely to have not only $50 \%$ of the active reservoir storage, but also the dominant portion of the natural storage as snowpack in the Columbia basin. In the US portion of the basin, loses of natural storage as snowpack are likely to create local impacts to summer flow that can only be mitigated by release of Canadian storage (Payne et al., 2004). Thus the creation of Canadian storage under the CRT that has broadly benefitted the US in many ways is also a source of vulnerability under climate change scenarios, because water that might otherwise have flowed unimpeded across the border in summer is now impounded in Canadian reservoirs. Canadian storage reservoirs are managed as lake ecosystems, which presents a fundamental conflict with potential releases of water to mitigate losses of summer flow in the US portion of the basin. These issues are complicated by the fact that the CRT, which is likely to be the foundation for transboundary negotiations between Canada and US related to climate change impacts, does not directly address issues related to instream flow augmentation.

When taken together these diverse institutional constraints support the argument that adaptive capacity to climate change impacts in the Columbia basin is inherently low in comparison with smaller and less institutionally complex systems such as the Seattle Water Supply system or the relatively well-coordinated water supply systems for irritation in Idaho discussed above.

This situation also implies that given the formidable institutional obstacles at the highest level of integration in the Columbia basin, effective adaptation may be more likely to occur at the sub-basin to local scale, and that efforts to develop practical adaptation strategies will shift to this arena where forward motion is less impeded by institutional constraints There is some evidence that this approach is a workable alternative, and in fact a number of sub-basin planning efforts are beginning to include adaptation to climate change as an element of long-term planning. Some recent examples of planning efforts the sub-basin scale include studies in the Okanagan basin in BC (Cohen et al., 2006) and Yakima (Vano et al., 2010b) and Methow River basins in WA. Similarly, adaptation at the community scale is also taking place, a notable example in the PNW being the Communities Adapting to Climate Change program sponsored by the Columbia Basin Trust in BC (http://www.cbt.org/Initiatives/ Climate_Change/?Adapting_to_Climate_Change). One reason why forward motion at the local and community scale is more easily achieved is that at these levels of governance there are often at most a few management entities responsible for decision making. At the community scale, for example, a small group of planners (or even in some cases a single individual) is usually responsible for long-range planning. Thus the decision making process at the local scale is framed by relationships between individuals living in the same community who are directly affected by the outcomes. Contrast this situation with the complex political and bureaucratic interactions between state and federal government representatives (or representatives of Canada and the US in an international setting) that must accompany major policy decisions affecting the Columbia basin as a whole.

While planning at the local scale is attractive because it avoids some of the main institutional obstacles discussed above, it remains less clear how all of these more local scale plans would be integrated to address the many pressing basin-wide concerns (Cohen et al., 2003). Basin-wide issues can also influence the effectiveness of adaptation at the local scale. For example, salmon recovery plans in the Methow and Yakima basins (both tributaries to the Columbia) are ultimately dependent on main stem fish survival for their 
success. If the combined effects of all the sub-basin plans do not ultimately support desirable outcomes for main stem conditions for fish, then the whole will be weakened. So while local scale planning may be effective at avoiding institutional paralysis, the need for enhanced regional scale coordination and communication between local planning efforts remains.

\section{Issues related to technical capacity and operational support services}

As discussed briefly above, technical capacity is an important element of climate change adaptation capacity. Many water management agencies currently have limited exposure to hydrologic modeling, which is an essential tool in assessing climate change impacts to streamflow and water system performance. Likewise the focus on simulation modeling as the basis for planning and a general lack of familiarity with optimization approaches poses some limitations on current adaptive capacity. Lee et al. (2009, 2010), for example, demonstrate that optimization techniques provide a potentially useful approach for rebalancing flood control operations in complex reservoir systems. Many water management agencies, however, do not currently have the technical capacity available to conduct these kinds of studies, nor are well-established procedures currently in place to guide water resources practitioners. As discussed below, these kinds of technical barriers to adaptation are gradually easing as water resources practitioners have embraced the technical challenges associated with climate change planning in collaborative efforts with academic researchers.

The robustness of operational services such as streamflow forecasts are also an important aspect of climate change adaptation. Some kinds of operational streamflow forecasts are already designed in such a way that they are "self tending", meaning that they automatically update themselves in a non-stationary climate. Others are not self tending and would either require repetitive interventions in response to poor performance as the climate changes, or would require more comprehensive changes to make them self tending.

An example of a self tending forecasting system is a flood forecasting system that is composed of operational weather forecasts dynamically coupled to a physically based hydrologic model. At least from a conceptual standpoint, for this system to work well in a warmer climate the weather forecasts would only need to incorporate increasing greenhouse gas concentrations or other adjustments to account for a systematically warmer climate. With this change in place the weather forecast models would presumably simulate appropriate changes in temperature and precipitation, which would then drive the physically based hydrologic model to estimate the appropriate flood risk over some future time window. While one might imagine that model calibration issues or other unexpected problems might emerge as the climate changes, resolving these issues would not require a policy intervention or a fundamental change in the forecasting system, only improvements in the models used, which is already an established objective of these programs. Furthermore, making weather forecast models work well in the new climate conditions is clearly an important objective in a number of contexts, and does not add costs in and of itself.

An example of a non-self-tending system would be a regression equation used to calculate the 100-yr flood based on annual precipitation statistics and basin area (such a system, developed by the USGS, is commonly used in the PNW for estimating flood risk in small, ungaged basins (http://water. usgs.gov/osw/streamstats/index.html). Because such a system does not include temperature or seasonal changes in precipitation (which are the primary drivers of hydrologic impacts in the PNW) as explanatory variables in the regression equation, estimates of future flood risk in temperature sensitive areas are unlikely to reflect changing conditions (Hamlet and Lettenmaier, 2007). Without reformulating the regression model to include additional explanatory variables or collecting new data to adjust the parameters in the regression equations these problems cannot be avoided under the current framework. Furthermore streamflow measurements may not be available in the most sensitive locations, which implies that the adjustments in training data for the regression models would not necessarily capture the most important changes. Replacing such a system with a more physically based hydrologic modeling approach that responds directly to temperature and seasonal precipitation change would tend to make the system more self tending, although validation remains a problem in ungaged locations.

Issues related to the design of water resources operating systems to cope with a non-stationary climate are similar in some ways to those associated with support services like streamflow forecasting systems discussed above. Operational decisions which are based on fixed reservoir rule curves (or other inflexible decision rules) are likely to require an expensive (and repetitive) policy intervention if climate change erodes the effectiveness of these management systems over time. Lee et al. (2010), for example, discuss these issues in the context of adapting flood control operations for climate change in the Columbia River basin. The Columbia basin currently uses a flood management system that adjusts the volume of flood evacuation in response to streamflow forecasts. This system is partly self tending in that forecasted changes in summer streamflow volumes in a warmer climate would automatically adjust the amount of flood control evacuation needed. However, Lee et al. (2009) demonstrate that evacuation schedules and the timing of refill would also need to change in response to streamflow timing shifts in order to maintain reservoir refill statistics. Because flood control materially affects many aspects of the Columbia's operations, a change in the current management system for flood control would require a full environmental impact assessment. Doing this multiple times would be extraordinarily expensive, and would thus create a barrier to adaptation. Furthermore, it 
is not clear exactly when (or how often) a new planning study or change in flood control operations should be implemented in a gradually changing climate. To avoid these problems, other kinds of flood control operating systems could be devised. One such scheme that has been put forward by Lee et al. (2010) is the concept of dynamic flood rule curves. In this system, the flood evacuation schedules for the entire system are optimized each month (using network optimization or other techniques) using ensemble streamflow forecasts from physically based hydrologic models. Such a system is "self tending" in that it responds dynamically to warmer temperatures or changes in precipitation which influence the streamflow forecasts and thereby the optimized flood evacuation requirements. These kinds of inherently flexible and self tending operational procedures present one way of coping with a non-stationary environment.

\section{Evidence of increased technical capacity and familiarity with climate change impacts}

The relatively recent development of a number of water management coalitions formed by groups of water management agencies to address the challenges of climate change planning is evidence that the issue is being taken seriously by these agencies, and that they are directly working with each other to increase adaptive capacity. Examples of these kinds of coalitions include collaborative efforts between the American Water Works Association, Association of Metropolitan Water Agencies, Water Utility Climate Alliance, Western Urban Water Coalition (http://www. wuwc.org/html/about_news.html), the Climate Change Collaboration $\left(\mathrm{C}^{3}\right)$ effort between federal management entities in OR, WA, ID (http://www.c3.gov/index.html), and the coordinated efforts of the Bonneville Power Administration, NW Power and Conservation Council, USACE and USBR in the Columbia River Basin under the direction of the River Management Joint Operating Committee for the Columbia basin. This rapidly expanding level of engagement on the issue of climate change represents a significant change in attitude over the last decade. In the late 1990s, many water managers felt that climate change was outside their sphere of influence and planning authority, and were often unwilling to engage with academics or other agencies on the issue (Gamble et al., 2002). With the change in federal administration in the US and an increasing awareness of climate change as an important issue, it has become increasingly clear that water management agencies will now be called upon to encompass climate change in their planning. In response, there is evidence that these agencies increasingly feel the need to take ownership of the processes of climate change impacts assessment and strategic adaptation planning. Similarly, as water management agencies have begun to realize that policy decisions related to climate change would significantly affect the regulatory environment pertaining to water, they have also felt an increasing need to control the messaging and the interaction with decision makers and policy makers. In one pivotal case involving the US Fish and Wildlife Service (USFWS) and USBR, the transition from indifference to engagement was fostered by a lawsuit challenging an Environmental Impact Statement (EIS) prepared by USFWS and the USBR in CA Natural Resources Defense Council vs. Kempthorne et al.; NRDC, 2007). NRDC argued successfully in the case that the USFWS's "no jeopardy" finding in the Sect. 7 biological opinion was "arbitrary, capricious, and contrary to law" because, among other things, the opinion did not take into account the impacts of climate change. In the wake of this suit, the USFWS and USBR quickly realized that they did not (at the time) have the capacity to address climate change impacts in studies like these, and that developing this capacity was suddenly now an urgent, practical need within the agencies. Prior to this, climate change planning had been seen more as an academic issue being imposed on the agencies from the outside. This case, in combination with a growing awareness of the potential impacts of climate change impacts, was arguably a significant factor relating to investment in capacity building in the USBR in the last three years. This lawsuit also represents a turning point for other major natural resources management agencies in the PNW, many of which were in essentially the same predicament with regard to existing capacity to address climate change impacts in planning studies.

The nature of these water management coalitions and their recent activities also suggests that the agencies involved now view the issues surrounding climate change differently than they have in the past. Climate change adaptation no longer means simply responding to needs related to impacts assessment and long-term planning, but now also has implications for institutional vulnerability related to changing political and regulatory risks. Water management agencies now feel vulnerable to potential policy responses to the climate change issue that may affect their regulatory responsibilities or management activities. While a shift to a more political viewpoint on the part of water management agencies may or may not have positive outcomes related to climate change adaptation (science and politics have been uneasy bedfellows in the past), the shift in strategy provides evidence of an increased awareness of the issue in the upper level leadership of water management agencies, and a desire to control outcomes related to climate change policy.

The development and use of specific information resources designed to support adaptation as a process is also evidence that climate change adaptation research and its user community are maturing. The widespread international use of the Climate Impacts Group's Adaptation Guidebook (Snover et al., 2007) (http://cses.washington.edu/cig/ fpt/guidebook.shtml) is one example of this growing capacity in both academia and professional practice. Likewise, synthesis documents on impacts and adaptation from the IPCC (http://www.ipcc.ch/ipccreports/ar4-wg2.htm) and 
regional assessment groups like the CIG (Whitely Binder et al., 2010) provide evidence that adaptation is being taken seriously in the US and Canada and in the larger international water community.

\section{Summary and conclusions}

Climate change is projected to profoundly affect the hydrology of the PNW, with important impacts to PNW water management systems. While mitigation of increasing greenhouse gas concentrations will play a major role in the level of impacts experienced at the end of the 21st century, impacts in the next several decades are not projected to respond to these factors. Thus adaptation will be a particularly important aspect of coping with climate change impacts in the near term.

The PNW has access to extensive water infrastructure, management capability, and support services. Thus in the short term, adaptive capacity to modest changes in climate is probably high in the PNW. This argument is supported by evidence of autonomous adaptation taking place in response to observed changes in natural variability, which although not necessarily caused by anthropogenic climate change per se, is consistent with projected future impacts in the region.

In large, complex water systems institutional barriers to adaptation abound, and it is unclear how these fundamental obstacles to change can be avoided. One approach may be to focus adaptation efforts primarily at the sub-basin scale, avoiding the institutional gridlock at the most fully integrated levels of governance. This also implies, however, that adaptation strategies that prove successful at the sub-basin scale probably cannot be "scaled up" to encompass the region as a whole.

There is considerable evidence that water resources management paradigms will need to be reformulated to cope with a non-stationary climate. Techniques that are inherently flexible and self-tending are likely to be preferred over rigid operating system constraints that are commonly encountered in current practice. The use of optimization techniques to create dynamic operating systems that respond to forecasts is one such approach.

Although progress towards climate change adaptation in the major water management agencies in the PWN has been limited in the past $15 \mathrm{yr}$ or so due to a number of factors, in the past three to five years there has been substantial investment in both increased technical capacity to achieve climate change adaptation objectives, and efforts to coordinate amongst various agencies to improve long-term planning and influence water policy at the national, state, and local level.

These efforts are being matched by steadily increasing resources being brought to bear on climate change research and the generation of products and services related to climate change adaptation in academia.
Acknowledgements. This publication is funded by the Joint Institute for the Study of the Atmosphere and Ocean (JISAO) under NOAA Cooperative Agreement No. NA17RJ1232, Contribution \#1822. Thanks to Rob Norheim at the Climate Impacts Group for cartographic services and figures. Thanks also to Gregory Greenwood (Mountain Research Initiative), Hans Schreier (University of British Columbia), and Jason Eisendorfer (Bonneville Power Administration) whose comments and suggestions during the review process substantially improved the paper.

Edited by: G. Greenwood

\section{References}

Bonneville Power Administration (BPA), US Army Corps of Engineers (USACE), NPD, US Bureau of Reclamation (USBR), PNR: The Columbia River system: The Inside Story, Report DOE/BP-1689, USACE, USBR and BPA, 1994.

Cohen, S. J., Miller, K., Hamlet, A., and Avis, W.: Climate Change and Resource Management in the Columbia River Basin, Water Int., 25(2), 253-272, 2000.

Cohen S., de Loe, R., Hamlet, A. F., Herrington, R., Mortsch, L., and Shrubsole, D.: Chapter 15 - Integrated and Cumulative Threats to Water Availability, in: Threats to Fresh Water Availability in Canada, Environment Canada, available at: http://www.nwri.ca/threats2full/intro-e.html, 2003.

Cohen, S., Neilsen, D., Smith, S., Neale, T., Taylor, B., Barton, M., Merritt, W., Alila, Y., Shepherd, P., McNeill, R., Tansey, J., Carmichael, J., and Langsdale, S.: Learning with local help: Expanding the dialogue on climate change and water management in the Okanagan Region, British Columbia, Canada, Climate Change., 75, 331-358, 2006.

Columbia Basin Bulletin: Salmon and Hydro: An Account of Litigation over Federal Columbia River Power System Biological Opinions for Salmon and Steelhead, 1991-2009, Columbia Basin Bulletin Issue Summary No. 1, First Addition, available at: http://www.cbbulletin.com/Issue+Summaries/default. aspx, February 2009.

Elsner, M. M., Cuo, L., Voisin, N., Deems, J. S., Hamlet, A. F., Vano, J. A., Mickelson, K. E. B., Lee, S. Y., and Lettenmaier, D. P.: Implications of 21 st century climate change for the hydrology of Washington State, Climate Change, 102(1-2), 225-260, doi:10.1007/s10584-010-9855-0, 2010.

Fereday, J. C., Meyer, C. H., and Creamer, M. C.: Water Law Handbook: The acquisition, use, transfer, administration, and management of water rights in Idaho, Givens-Pursley, LLP, Boise, Idaho, available at: http://www.givenspursley.com/Publications. aspx, 2009.

Gamble, J. L., Furlow, J., Snover, A. K., Hamlet, A. F., Morehouse, B. J., Hartmann, H., and Pagano, T.: Assessing the Impact of Climate Variability and Change on Regional Water Resources: The Implications for Stakeholders, in: Water: Science, Policy, and Management, edited by: Lawford, R., Fort, D. D., Hartman, H. C., and Eden, S., AGU Press Monograph, 2002.

Gray, K. N.: The impacts of drought on Yakima Valley irrigated agriculture and Seattle municipal and industrial water supply, M.M.A. thesis, School of Marine Affairs, University of Washington, Seattle, 1999. 
Hamlet, A. F.: The Role of Transboundary Agreements in the Columbia River Basin: An Integrated Assessment in the Context of Historic Development, Climate, and Evolving Water Policy, in: Climate and Water: Transboundary Challenges in the Americas, edited by: Diaz, H. and Morehouse, B., Kluwer Press, Dordrecht/Boston/London, 2003.

Hamlet, A. F. and Lettenmaier, D. P.: Effects of Climate Change on Hydrology and Water Resources in the Columbia River Basin, J. Am. Water Resour. As., 35(6), 1597-1623, 1999.

Hamlet A. F. and Lettenmaier, D. P.: Effects of 20th Century Warming and Climate Variability on Flood Risk in the Western US, Water Resour. Res., 43, W06427, doi:10.1029/2006WR005099, 2007.

Hamlet, A. F., Lee, S. Y., Mickelson, K. E. B., and Elsner, M. M.: Effects of projected climate change on energy supply and demand in the Pacific Northwest and Washington State, Climate Change, 102(1-2), 103-128, doi:10.1007/s10584-010-9857-y, 2010.

Independent Scientific Advisory Board (ISAB): Climate Change Impacts on Columbia River Basin Fish and Wildlife, ISAB Climate Chang Rep., available at: http://www.nwcouncil.org/ library/isab/isab2007-2.htm (last access: 29 April 2011), 2007.

Labadie, J. W.: Optimal Operation of Multireservoir Systems: State-of-the-Art Review, J. Water Res. Pl.-ASCE, 130(2), 93111, 2004.

Lee, S.-Y., Hamlet, A. F., Fitzgerald, C. J., and Burges, S. J.: Optimized Flood Control in the Columbia River Basin for a Global Warming Scenario, J. Water Res. Pl.-ASCE, 135(6), 440-450, doi:10.1061/(ASCE)0733-9496(2009)135:6(440), 2009.

Lee, S. Y., Hamlet, A. F., Fitzgerald, C. J., and Burges, S. J.: Daily Time Step Refinement of Optimized Flood Control Rule Curves for a Global Warming Scenario, J. Water Res. Pl.-ASCE, doi:10.1061/(ASCE)WR.1943-5452.0000125, 2010.

Lund, J. R. and Ferreira, I.: Operating Rule Optimization for Missouri River Reservoir System, Water Res. Pl.-ASCE, 122(4), 287-295, 1996.

Mantua, N., Tohver, I., and Hamlet, A. F.: Climate change impacts on streamflow extremes and summertime stream temperature and their possible consequences for freshwater salmon habitat in Washington State, Climate Change, 102(1-2), 187-223, doi:10.1007/s10584-010-9845-2, 2010.

Medellin-Azuara, J., Harou, J. J., Olivares, M. A., Madani, K., Lund, J. R., Howitt, R. E., Tanaka, S. K., Jenkins, M. W., and Zhu, T.: Adaptability and adaptations of California's water supply system to dry climate warming, Climate Change, 87, S75S90, 2008.

Miles, E. L., Snover, A. K., Hamlet, A. F., Callahan, B., and Fluharty, D.: Pacific Northwest regional assessment: The impacts of climate variability and climate change on the water resources of the Columbia River Basin, J. Am. Water Res. As., 36(2), 399-420, 2000.

Mote, P. W. and Salathé, E. P.: Future climate in the Pacific Northwest. Climate Change, 102(1-2), 29-50, doi:10.1007/s10584010-9848-z, 2010.

Mote, P. W., Hamlet, A. F., Clark, M. P., and Lettenmaier, D. P.: Declining mountain snowpack in western North America, Bull. Am. Meteorol. Soc., 86(1), 39-49, 2005.

Mote, P. W., Hamlet, A., and Salathé, E.: Has spring snowpack declined in the Washington Cascades?, Hydrol. Earth Syst. Sci.,
12, 193-206, doi:10.5194/hess-12-193-2008, 2008.

NRDC: Natural Resources Defense Council et al. vs. Kempthorne, et al., US District Court, Eastern District of California, No. 1:05cv-1307 OWW GSA, 2007.

Payne, J. T., Wood, A. W., Hamlet, A. F., Palmer, R. N., and Lettenmaier, D. P.: Mitigating the effects of climate change on the water resources of the Columbia River basin, Climate Change, 62(1-3), 233-256, 2004.

Stakhiv, E. Z.: Water Resources Planning and Management Under Climate Uncertainty, in: Proceedings of the First National Conference on Climate Change and Water Resources Management, edited by: Ballentine, T. M. and Stakhiv, E. Z., US Army Corps of Engineers Institute for Water Resources, Fort Belvoir, VA, IV20-35, 1993.

Slaughter, R. A.: A transactions cost approach to the theoretical foundations of water markets, J. Am. Water Res. As., 45(2), 331342, doi:10.1111/j.1752-1688.2008, 2009.

Slaughter, R. and Wiener, J. D.: Water, adaptation, and property rights on the Snake and Klamath Rivers, J. Am. Water Res. As., 43(2), 308-321, doi:10.1111/j.1752-1688.2007.00024.x, 2007.

Slaughter, R., Hamlet, A. F., Huppert, D. D., Hamilton, J., and Mote, P.W.: Mandates vs. markets: Addressing over-allocation of Pacific Northwest river basins, Water Policy, 12, 305-317, doi:10.2166/wp.2009.152, 2010.

Slaughter, R., Hamlet, A. F., Huppert, D. D., Hamilton, J., and Mote, P.W.: Mandates vs. markets: Addressing over-allocation of Pacific Northwest river basins, Water Policy, 12, 305-317, doi:10.2166/wp.2009.152, 2010.

Snover, A. K., Whitely Binder, L., Lopez, J., Willmott, E., Kay, J., Howell, D., and Simmonds, J.: Preparing for Climate Change: A Guidebook for Local, Regional, and State Governments, in association with and published by ICLEI - Local Governments for Sustainability, Oakland, CA, 2007.

Stedinger, J. R., Vogel, R. M., and Foufoula-Georgiou, E.: Frequency analysis of extreme events, Handbook of Hydrology, edited by: Maidment, D. R., McGraw-Hill, Inc, New York, 1993.

Tohver, I. and Hamlet, A. F.: Impacts of 21 st century climate change on hydrologic extremes in the $\mathrm{Pa}$ cific Northwest region of North America, available at: http://www.hydro.washington.edu/2860/products/sites/ r7climate/study_report/CBCCSP_chap7_extremes_final.pdf, 2010.

Vano, J. A., Voisin, N., Cuo, L., Hamlet, A. F., Elsner, M. M., Palmer, R. N., Polebitski, A., and Lettenmaier, D. P.: Climate change impacts on water management in the Puget Sound Region, Washington, USA, Climate Change, 102(1-2), 261-286, doi:10.1007/s10584-010-9846-1, 2010a.

Vano, J. A., Scott, M., Voisin, N., Stöckle, C. O., Hamlet, A. F., Mickelson, K. E. B., Elsner, M. M., and Lettenmaier, D. P.: Climate change impacts on water management and irrigated agriculture in the Yakima River basin, Washington, USA, Climate Change, 102(1-2), 287-317, doi:10.1007/s10584-010-9856-z, 2010b.

Washington Department of Ecology (WDOE): Analysis of Water Banks in the Western States, Ecology Publication No. 04-11-011, 2004.

Whitely Binder, L. C. with contributions from Barcelos, J. K., Booth, D. B., Darzen, M., McGuire Elsner, M., Fenske, R., Graham, T. F., Hamlet, A. F., Hodges-Howell, J., Huppert, D. 
D., Jackson, J. E., Karr, C., Keys, P. W., Littell, J. S., Mantua, N., Marlow, J., McKenzie, D., Robinson-Dorn, M., Rosenberg, E. A., Stöckle, C. O., and Vano, J. A.: Preparing for Climate Change in Washington State, Climate Change, 102(1-2), 351376, doi:10.1007/s10584-010-9850-5, 2010.
Wiley, M. W.: Analysis techniques to incorporate climate change information into Seattle's long range water supply planning, M.S.C.E. thesis, Department of Civil and Environmental Engineering, University of Washington, Seattle, 2004. 